\title{
Upaya Peningkatan Pengelolaan Koperasi Simpan Pinjam Pada Sekolah Menengah Umum di Kecamatan Jagakarsa
}

\author{
Irma Setyawati ${ }^{1}$ \\ Universitas Bhayangkara Jakarta Raya, setyawati@yahoo.com \\ Sugeng Suroso ${ }^{2}$ \\ Universitas Bhayangkara Jakarta Raya, sugeng.suroso@ubharajaya.ac.id \\ Delila Rambe ${ }^{3}$ \\ Institut Bisnis dan Informatika Kosgoro 1957, lila_rambe@yahoo.com \\ Prisila Damayanty ${ }^{4}$ \\ Institut Bisnis dan Informatika Kosgoro 1957, prisild@rocketmail.com \\ Tyastuti Sri Lestari ${ }^{5}$ \\ Universitas Bhayangkara Jakarta Raya, tyas.ismono@gmail.com
}

\begin{abstract}
Abstrak
Perkembangan ilmu dan teknologi semakin mendorong usaha-usaha ke arah pembaharuan dalam memanfaatkan hasil-hasil teknologi dalam rangka meningkatkan tertib administrasi dan profesionalisme. Guru (pengajar) dalam rangka memperoleh tugas tambahan sebagai pengurus koperasi di SMU selayaknya memperoleh pelatihan untuk melakukan pengadministrasian peminjaman di koperasi dengan menggunakan program-program aplikasi. Tujuan dari kegiatan penfabdian kepada masyarakat ini adalah wahana transfer ilmu kepada masyarakat sasaran. Dengan metode pendampingan langsung kepada guru pengurus koperasi SMA di wilayah Kecamatan Jagakarsa, diharapkan data finansial tercatat dalam komputer, penggunaan program aplikasi dapat menentukan bunga pinjaman, angsuran pinjaman dan bunga simpanan, peningkatan kemampuan sumber daya manusia untuk mengelola usaha simpan pinjam. Pengabdian ini dilaksanakan dengan peserta guru SMU di Kecamatana Jagakarsa Jakarta Selatan yang diberi tugas tambahan sebagai pengurus koperasi di SMU-nya masing-masing. Materi pelatihan adalah program aplikasi untuk koperasi simpan pinjam. Peserta pelatihan menunjukkan respon antusias dan hasil pelatihan menunjukkan hasil beberapa peserta pelatihan mampu menagkap dan mengaplikasikannya.
\end{abstract}

Kata Kunci: Koperasi, Simpan Pinjam, Program Aplikasi, Jagakarsa

\section{Abstract}

The development of science and technology increasingly pushes efforts towards renewal in utilizing the results of technology in order to improve the orderly administration and professionalism. Teachers in order to obtain additional duties as cooperative managers in SMU should get training to perform lending administration procedures in cooperatives by using application programs. The purpose of this activity is to facilitate the transfer of knowledge to the target community. With direct assistance method to high school cooperative 
teachers in Jagakarsa sub-district, it is expected that financial data is recorded in computer, application program usage can determine loan interest, loan installment and deposit interest, human resource capacity improvement to manage saving and loan business. This devotion is carried out with the participants of high school teachers in Jagakarsa sub-district, South Jakarta who are given additional duty as caretaker of cooperatives in their respective high school. Training materials are application programs for savings and credit cooperatives. The training participants showed enthusiastic response and training results showed the results of some trainees were able to capture and apply them.

Keywords: Cooperative, Savings and Loans, Application Program, Jagakarsa

\section{Pendahuluan}

Kecamatan Jagakarsa adalah satu dari sepuluh kecamatan dalam wilayah Kotamadya Jakarta Selatan. Secara geografis, kecamatan Jagakarsa terletak pada bagian selatan yang berbatasan dengan Kota Administratif Depok. Pembentukan wilayah administratif kecamatan didasarkan pada Peraturan Pemerintah Nomor 60 tahun 1990 tanggal 18 Desember 1990, tentang pembentukan Kecamatan dalam wilayah daerah Khusus Ibukota Jakarta. Luas wilayah Kecamatan Jagakarsa meliputi 2.502.500 Ha.

Penerimaan Pendapatan Asli Daerah (PAD) berasal dari pajak reklame, pajak hotel dan restauran, pajak hiburan, tata kota dan pajak bumi bangunan. Sarana pendidikan di Kecamatan Jagakarsa terdapat pada Tabel 1.

Tabel 1. Sarana Pendidikan di Kecamatan Jagakarsa

\begin{tabular}{llcccccc}
\hline No & Kelurahan & SLB & TK & SD & SMP & SMU & PT \\
\hline 1. & Ciganjur & - & 13 & 8 & 1 & 2 & - \\
\hline 2. & Srengseng Sawah & 1 & 14 & 22 & 12 & 11 & 2 \\
\hline 3. & Jagakarsa & 1 & 12 & 21 & 7 & 12 & 2 \\
\hline 4. & Lenteng Agung & 1 & 8 & 16 & 6 & 5 & 2 \\
\hline 5. & Tanjung Barat & - & 10 & 16 & 7 & 4 & 1 \\
\hline & TOTAL & 3 & 57 & 83 & 33 & 34 & 7 \\
\hline
\end{tabular}

Sumber: Monografi Kecamatan Jagakarsa (2014)

Perkembangan teknologi informasi yang pesat telah menyebabkan perubahan besar dalam operasi suatu perusahaan, termasuk koperasi. Koperasi adalah organisasi bisnis yang dimiliki dan dioperasikan oleh orang-orang demi kepentingan bersama, kegiatannya berdasarkan prinsip gerakan ekonomi rakyat yang berdasarkan asas kekeluargaan (Saraswati \& Yadnyana, 2014). Sesuai dengan amanat dari pasal 33 Undang-Undang Dasar 1945, adalah dengan mendirikan lembaga - lembaga perekonomian rakyat, salah satunya adalah koperasi, sebagai salah satu cara yang ditempuh pemerintah untuk meningkatkan kesejahteraan masyarakat.

Koperasi sebagai soko guru perekonomian seharusnya mengikuti perkembangan teknologi informasi, sehingga tidak tertinggal dalam pengembangan kegiatan usahanya. Dalam perkembangannya, banyak koperasi berhenti di tengah jalan karena kurang baiknya pengelolaan yang dilakukan oleh pengurusnya, di mana mereka menganggap bahwa koperasi hanya sebagai pekerjaan sambilan setelah menyelesaikan pekerjaan utama, akan tetapi banyak pula koperasi yang berkembang karena pengelolaan dilakukan secara professional (Muljono, 2012). 
Tujuan didirikannya koperasi adalah (1) membangun dan mengembangkan potensi dan kemampuan ekonomi setiap anggota pada khususnya dan masyarakat pada umumnya untuk selalu meningkatkan dan mempertahankan kesejahteraan ekonomi masyarakat, (2) berperan serta secara aktif dalam upaya meningkatkan dan memperbaiki kualitas kehidupan manusia dan masyarakat, (3) memperkokoh perekonomian rakyat sebagai dasar kekuatan dan ketahanan perekonomian nasional dengan koperasi sebagai soko gurunya, (4) berusaha untuk mewujudkan dan mengembangkan perekonomian nasional, yang merupakan usaha bersama berdasarkan atas asas kekeluargaan dan demokrasi ekonomi (Kantor Kepresidenan Republik Indonesia, 2012).

Sedangkan manfaat koperasi bagi masyarakat adalah (1) menawarkan barang dan jasa dengan harga yang lebih terjangkau bagi anggota koperasi yang kurang mampu untuk memiliki sebuah barang atau jasa dikarnakan harga yang mahal, melalui koperasi bisa mendapatkan harga barang atau jasa yang ditawarkan bisa lebih murah dan terjangkau dibanding dengan toko-toko lain selain koperasi, (2) menumbuhkan motivasi usaha anggota koperasi agar lebih berperilaku kemanusiaan. Selain dituntut untuk meraih sebuah keuntungan serta semangat dalam berwirausaha, koperasi juga memiliki tujuan mulia yaitu untuk melayani dengan baik keperluan anggotanya sehingga kebutuhan dan keperluan anggotanya terpenuhi, (3) menumbuhkan sikap jujur dan terbuka. Dalam pengelolaan koperasi setiap anggota memiliki tugas masing-masing. Lebih mengedepankan sikap terbuka dan kejujuran dalam menyampaikan laporan. Kejujuran adalah modal utama dalam suatu hubungan, terutama koperasi yang mengedepankan sikap kekeluargaan terhadap semua anggotnya (Kantor Kepresidenan Republik Indonesia, 2012).

Salah satu kegiatan yang dilakukan koperasi adalah usaha simpan pinjam. Usaha simpan pinjam adalah kegiatan menghimpun dan menyalurkan dana melalui usaha simpan pinjam dari dan untuk anggota koperasi. Kegiatan usaha simpan pinjam dilaksanakan oleh Koperasi Simpan Pinjam (KSP) maupun Unit Simpan Pinjam (USP) (Aini \& Setiawan, 2006). Koperasi simpan pinjam dapat ditemukan di sebuah perusahaan, kantor pemerintah, lembaga pendidikan, dan sebagainya, yang memiliki banyak karyawan atau pegawai. Berdirinya koperasi tersebut untuk memenuhi berbagai kebutuhan seperti sembako, barang elektronik, maupun kebutuhan finansial. Hal yang umum terjadi, para anggota koperasi membeli sembako atau meminjam uang pada koperasi dan pembayarannya dilakukan secara mengangsur, dengan memotong sebagian gaji karyawan yang bersangkutan (Cahyani, 2015).

Pemberian pinjaman merupakan bisnis yang berisiko, karena terdapat kemungkinan pinjaman yang diberikan tidak dapat tertagih (macet). Sudah menjadi keharusan bagi koperasi hanya memberikan pinjaman kepada anggota yang layak dengan menyeleksi setiap usulan pinjaman. Proses tersebut dinamakan analisis kredit, yang dilakukan oleh pengurus kopersi untuk menentukan seberapa besar dana yang dapat dipinjamkan ke anggota berdasarkan iuran pokok dan sukarela yang telah terkumpul sebagai anggota dan sejarah pinjaman masa lalu (Ayuk \& Utama, 2011).

Dengan jumlah Sekolah Menengah Umum (SMU) di daerah Kecamatan sebagaimana terlihat pada tabel 1, maka sangat diperlukan pencatatan data finansial pada 
koperasi yang didirikan di tiap-tiap SMU tersebut. Pencatatan secara manual dan bertumpu pada alat bantu kalkulator akan mengakibatkan pengadministrasian pinjaman anggota tidak akurat. Untuk itu diperlukan alat bantu komputer dan programnya untuk membantu pemrosesan data. Kendala yang dihadapi koperasi adalah masih langkanya program aplikasi yang digunakan untuk keperluan administrasi simpan pinjam di samping sumber daya manusia yang dimiliki belum cukup kompetensinya.

Penyuluhan tentang pencatatan data finansial dengan menggunakan metode program aplikasi untuk administrasi simpan pinjam, diberikan oleh tim pengabdi dengan metode pendampingan langsung kepada guru pengurus koperasi SMA di wilayah Kecamatan Jagakarsa. Tujuannya agar kegiatan ini dapat menjadi wahana transfer ilmu kepada masyarakat sasaran. Kontribusi dari kegiatan pengabdian ini diharapkan (1) data finansial tercatat dalam komputer, (2) penggunaan program aplikasi dapat menentukan bunga pinjaman, angsuran pinjaman dan bunga simpanan, (3) peningkatan kemampuan sumber daya manusia untuk mengelola usaha simpan pinjam.

\section{Metode}

Usaha simpan pinjam pada koperasi selalu berkaitan dengan biaya dana, bunga pinjaman, angsuran pinjaman dan bunga simpanan. Padahal dalam koperasi terdapat 2 (dua) kelompok, yaitu anggota dan bukan anggota koperasi, oleh karenanya credit rating dari masing-masing kelompok berbeda. Prime rate biasanya diberikan kepada anggota (prime customer) dan non-prime rate untuk bukan anggota (non-prime customer). Tingkat bunga non-primecustomer lebih tinggi dibandingkan dengan prime customer. Oleh karena itu, banyak perhitungan dalam usaha simpan pinjam koperasi, di mana perhitungan tersebut dapat dilakukan dengan mudah dengan aplikasi yang terdapat dalam komputer. Metode pemecahan masalah dilakukan dengan:

1. Penyuluhan, berupa pengenalan program aplikasi,

2. Praktek dengan studi kasus.

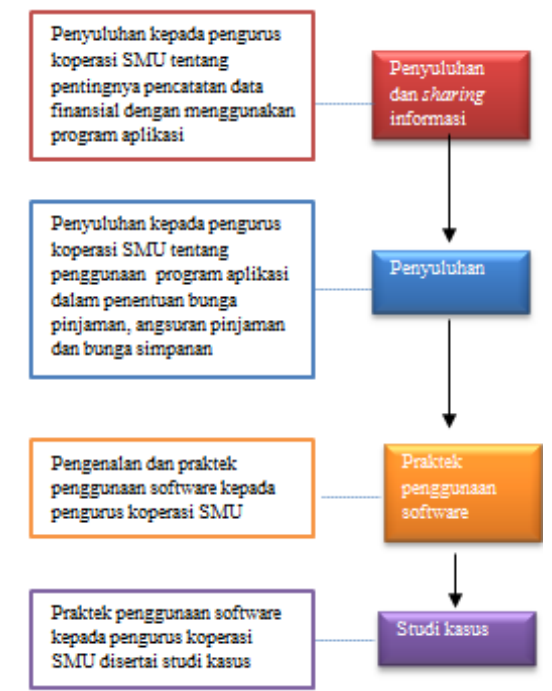

Gambar 1. Kerangka Pemecahan Masalah 


\section{Hasil Dan Pembahasan}

Sekolah/pendidikan dapat menjadi tempat yang efektif untuk menyuburkan karakteristik dan kemampuan untuk melakukan inovasi. Kata "dapat menjadi", karena sekolah memerlukan penyesuaian terlebih dahulu agar bisa menjalankan fungsi ini. Hal ini tetap memerlukan peran pemerintah dengan mempercepat proses penyesuaian tersebut, misalnya menetapkan regulasi kurikulum sekolah (Setiawan, 2002).

Kegiatan pengabdian ini diikuti oleh 23 peserta yang terdiri dari guru yang merupakan pengurus koperasi di SMU-nya masing-masing. Setiap SMU mengirimkan 1 (satu) pengurus, dengan demikian terdapat 23 SMU. Penyuluhan dilakukan dalam 2 (dua) hari, yaitu pada tanggal 18 - 19 April 2017. Pelaksanaan penyuluhan di aula Institut Bisnis dan Informatika Kosgoro 1957 di Jalan RM Kahfi II No. 33 Srengseng Sawah, Jagakarsa, Jakarta Selatan. Perwakilan SMU yang hadir dari tiap-tiap kelurahan disajikan pada Tabel 2.

Tabel 2. Kehadiran Perwakilan SMU tiap-tiap Kelurahan

\begin{tabular}{llcc}
\hline No & Kelurahan & SMU & $\%$ \\
\hline 1. & Ciganjur & 1 & 4,3 \\
\hline 2. & Srengseng Sawah & 8 & 34,8 \\
\hline 3. & Jagakarsa & 7 & 30,4 \\
\hline 4. & Lenteng Agung & 4 & 17,4 \\
\hline 5. & Tanjung Barat & 3 & 13,1 \\
\hline \multicolumn{2}{r}{ TOTAL } & 23 \\
\hline
\end{tabular}

Peserta program pengabdian kepada masyarakat ini sebagian besar didominasi oleh wanita, yaitu sebesar 60\% (Gambar 2). Hal ini dimungkinkan karena wanita lebih teliti dalam melakukan pembukuan dan membuat anggaran pengelolaan keuangan rumah tangga.

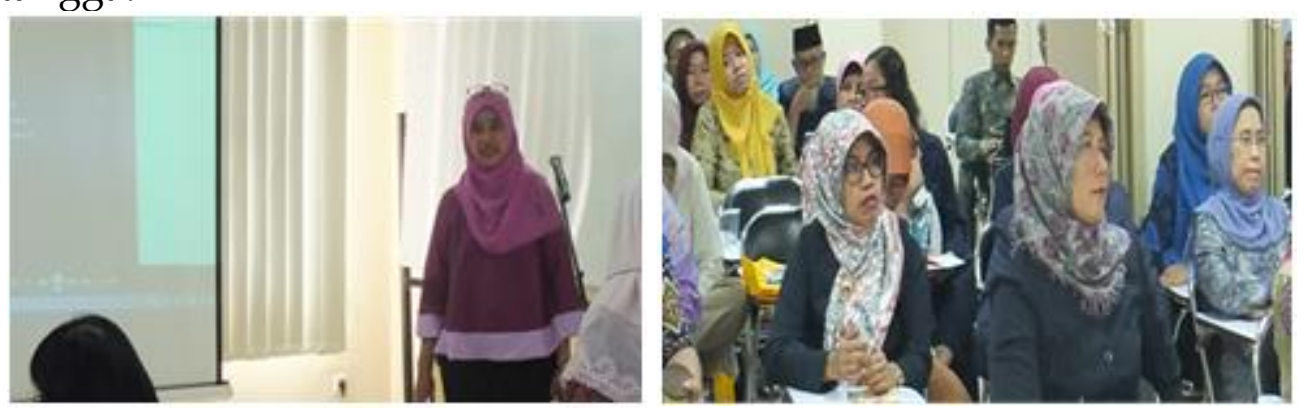

Gambar 2. Pelaksanaan Kegiatan Pengabdian Kepada Masyarakat

\section{Pembentukan Koperasi}

Berdasarkan sharing dengan pengurus koperasi SMU, unit usaha simpan pinjam mulai dilaksanakan seiring dengan terbentuknya koperasi tersebut. Koperasi SMU di lingkungan Kecamatan Jagakarsa telah memiliki anggaran dasar dan rumah tangga, ketentuan-ketentuan terkait dengan simpan pinjam, akan tetapi belum teradministrasi dengan baik dan masih menggunakan cara manual. 


\section{Materi Penyuluhan}

Penentuan tingkat bunga non-prime rate dipengaruhi oleh tingkat risiko atas pinjaman, misalkan untuk pinjaman konsumtif karena tingkat risiko lebih tinggi dibandingkan pinjaman usaha, maka bunga pinjaman lebih besar atau di atas prime rate. Sedangkan tingkat bunga prime rate dapat ditentukan melalui 2 (dua) pendekatan, yaitu marginal cost concept dan weighted average cost of fund concept.

1. Marginal cost concept

Dalam konsep ini didasarkan pada biaya dana yang relevan, yaitu bunga yang harus dibayar saat ini. Sebagai contoh, suatu perusahaan mengajukan pinjaman ke bank sebesar Rp 1 milyar, selanjutnya bank mencari sumber dana di pasar uang dengan quotation sebesar $13 \%$ per tahun. Bagi bank, 13\% merupakan cost of fund dan selanjutnya bank akan menentukan prime rate dengan menambahkan spread (keuntungan yang diharapkan) pada cost of fund tersebut. Jika bank menghendaki spread sebesar $2 \%$, maka prime rate sebesar $15 \%$, yang terdiri dari cost of fund $15 \%+$ spread $2 \%$. Secara matematis, perhitungan prime rate dalam pendekatan marginal cost concept dapat dihitung dengan rumus cost of fund + spread.

2. Weighted average cost of fund concept

Dalam pendekatan weighted average cost of fund concept, sumber dana yang diterima secara proporsional dikalikan dengan presentase biaya dana yang dibayarkan dari masing-masing sumber dan untuk memperoleh dna yang efektif (jumlah dana - cadangn wajib. Dengan demikian dapat diketahui kontribusi dari masing-masing sumber dana yang diterima. Total kontribusi masing-masing sumber dana (total cost of fund) merupakan salah satu komponen untuk menentukan besarnya base lending rate (BLR) yang merupakan pokok penjualan (cost of good sold). Penentuan tingkat bunga prime rate dalam pendekatan ini memerlukan data sebagai berikut:

a. Dana (sumber dana) yang diterima bank dapat berupa giro, tabungan dan deposito. Jika konsep ini diterapkan di koperasi, sumber dana tersebut meliputi simpanan pokok, simpanan wajib, simpanan sukarela, pinjaman pada bank maupun pinjaman lain,

b. Biaya dana (cost of fund) yang dibayarkan pada masing-masing sumber dana dipengaruhi oleh struktur sumber dana, tingkat bunga, reserve requirement, peraturan perpajakan dan lokasi pasar.

\section{Bunga Kredit dan Tabel Angsuran Pinjaman}

Angsuran yang harus dibayar peminjam dipengaruhi oleh pokok pinjaman, jangka waktu peminjaman dan tingkat suku bunga yang berlaku. Setelah tingkat suku bunga diketahui, maka dihitung berapa besar bunga pinjaman yang dibebankan kepada peminjam setiap kali mengangsur pokok pinjaman selama jangka waktu tertentu. Besarnya bunga pinjaman yang dibayarkan oleh anggota dapat dihitung berdasarkan sistem yang dipakai, yaitu sliding (menurun), flat (tetap) atau efektif.

1. Sistem Sliding

Perhitingan dengan sistem sliding atau model adjusted rate mortgage akan menghasilkan bunga yang semakin menurun. Dengan demikian angsuran 
pinjaman dari periode ke periode juga akan menurun. Perhitungan bunga didasarkan pada saldo pinjaman yang semakin mengecil, secara matematis dapat dihitung dengan rumus sebagai berikut:

$$
=\frac{(\text { saldo pinjaman } x \text { bunga per tahun })}{12}
$$

2. Sistem Flat

Perhitungan bunga dengan sistem flat atau model constant payment mortgage, mengasilkan agsuran pinjaman yang tetap dari periode ke periode. Hal ini disebabkan bunga dihitung tetap dari pokok pinjaman awal. Secara matematis dapat dihitung dengan rumus:

3. Sistem Efektif

$$
=\frac{\text { (pokok pinjaman awal } x \text { bunga per tahun })}{12}
$$

Perhitungan bunga dengan sistem efektif, Excel telah menyediakan fungsi untuk menghitung bunga pinjaman, cicilan pokok pinjaman dan pembayaran agsuran yang menjadi kewajiban peminjam.

\section{Fungsi Principal Payment (PPMT)}

Fungsi Principal Payment (PPMT) digunakan untuk menghitung pokok pinjaman dari suatu pembayaran angsuran. Bentuk fungsi PPMT adalah:

=PPMT(rate;period;number_of_period;present_value;future_value;type)

Fungsi Interest Payment (IPMT)

Fungsi Interest Payment (IPMT) digunakan untuk menghitung bunga atau bagian dari pembayaran angsuran pada tingkat bunga efektif. Bentuk fungsi PPMT adalah: =IPMT(rate;period;number_of_period;present_value;future_value;type)

\section{Fungsi Payment (PMT)}

Fungsi Payment (PMT) digunakan untuk menghitung pokok pinjaman dari suatu pembayaran angsuran dengan bunga efektif selama periode tertentu. Bentuk fungsi PPMT adalah:

=PMT(rate;number_of_period;present_value;future_value;type)

Keterangan

- Rate : tingkat suku bunga pinjaman (dalam periode tahun)

- Period : periode pembayaran (dalam waktu bulan)

- nper : jumlah periode pembayaran (dalam waktu bulan)

- present value : nilai pinjaman

- future value : nilai yang akan datang

- type : tipe pembayaran untuk menentukan waktu pembayaran dilakukan, 0 (nol) untuk akhir periode atau 1 (satu) untuk awal periode

\section{Tabel Angsuran Pinjaman}

Prosedur untuk membuat tabel angsuran pinjaman sebagai berikut:

1. Susun data anggota koperasi dalam sebuah lembar kerja (sheet) tersendiri. Contoh dapat dilihat pada Gambar 3. 


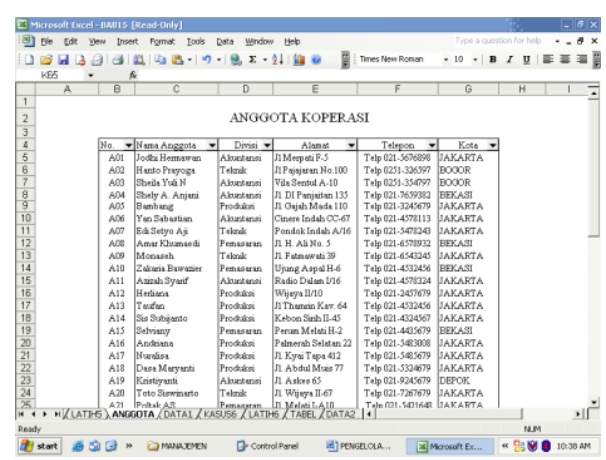

Gambar 3. Susunan Anggota Koperasi

Untuk memudahkan penampilan data peminjam, harus memberikan nama range Anggota Koperasi yang terdapat pada sheet ANGGOTA. Contoh nama range yang digunakan dalam kasus ini adalah:

a. Range B5:G54, dengan nama alamat

b. Range B5:B54, dengan nama kode

Jika akan menambah kolom dan jumlah nggota, sorot semua data anggota (tidak termasuk judul kolom), selanjutnya tambahkan sel pada nama range tersebut. Misal telah diubah judul kolom dan memasukkan identitas anggota (tanpa judul) berarti pada range B5:H450 dan kode anggota berada pada range B5:B450.

Prosedur menambahkan sel pada nama range dengan asumsi sheet yang berisi anggota telah diaktifkan adalah sebagai berikut:

a. Pilih dan klik menu Insert-Name selanjutnya klik pilihan Define. Jendela Define Name ditampilkan.

b. Pilih atau sorot nama range yang akan ditambahkan sel; dalam kasus ini Alamat.

c. Klik tombol pencari (finder) yang terdapat di posisi kiri bawah, lihat Gambar 4 berikut:

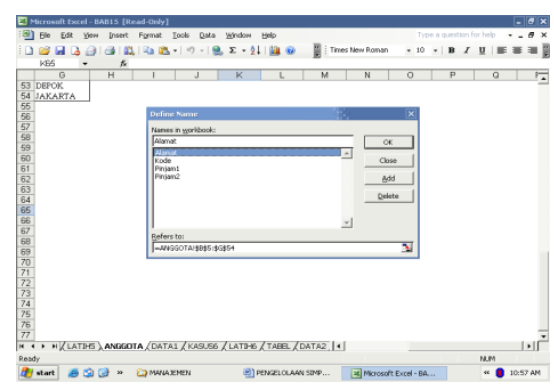

Gambar 4. Penambahan Anggota Koperasi

d. Jendela Define Name-Refers to: ditampilkan, sorot alamat sel (dalam kasus ini B5:H450) yang dikehendaki. Langkah yang sama dilakukan untuk nama range kode (B5:B450).

2. Tombol pilihan untuk bunga pinjaman dibuat dengan prosedur sebagai berikut:

a. Aktifkan toolbar forms melalui menu View-Toolbars pilihan forms. Selanjutnya pilih tombol Spinner (dalam kasus ini), seperti terlihat pada Gambar 5. 


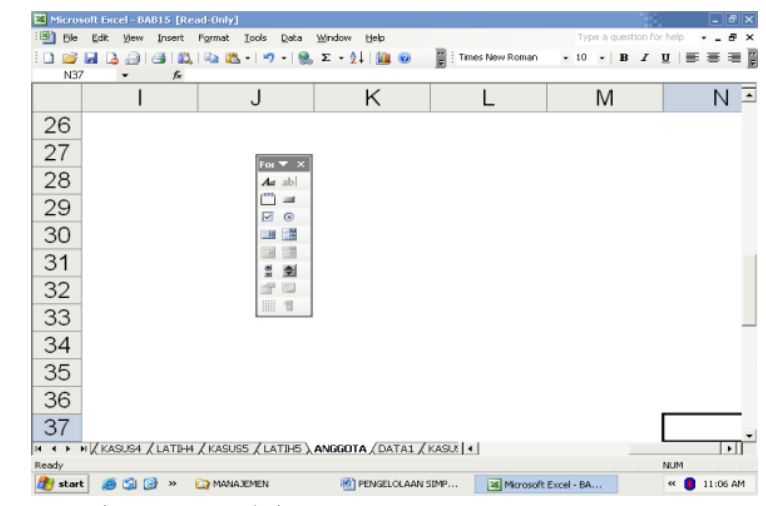

Gambar 5. Pilihan Bunga Pinjaman

b. Setelah tombol ditempatkan, klik tombol mouse sebelah kanan dan pilih Format Control, jendela format control ditampilkan.

c. Tentukan nilai minimum, maksimum, perubahan untuk setiap kenaikan nilai (incremental change) dan penempatan nilai pilihan sebagai dasar pemberian keterangan untuk sistem bunga yang dipilih.

Berdasarkan data tersebut pilihan hanya 3 (nilai maksimum), jika diklik tombol tersebut akan menghasilkan angka 1, 2, atau 3 yang ditempatkan pada alamat sel F5, sebagaimana terlihat pada Gambar 6.

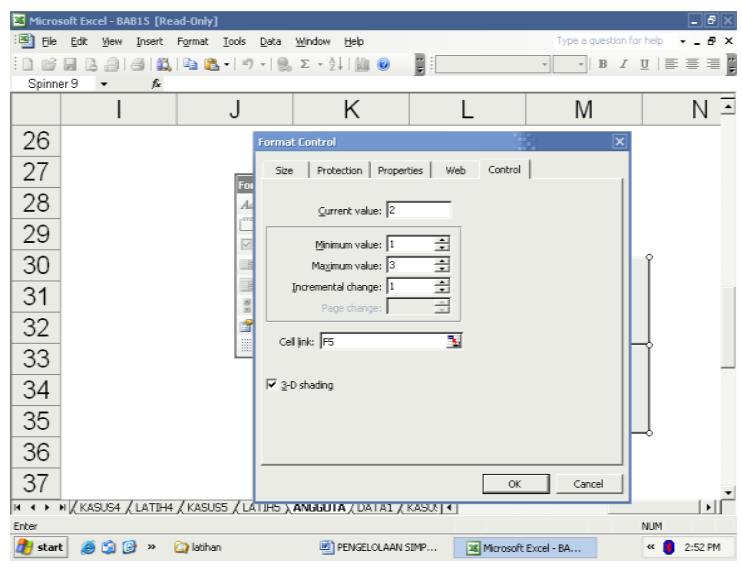

Gambar 6. Pilihan Sistem Bunga

d. Angka pilihan pada sel F5 akan lebih informatif jika ditampilkan dalam teks : sliding rate, flat rate dan effective rate, sehingga pada almat sel F9 diisi fungsi: =IF(F5=1;"Sliding rate";IF(F5=2;Flate Rate;"Efektif"))

3. Pengisian data Nomor Anggota pada sel D13 (sheet kasus 6), menggunakan fasilitas data dengan prosedur berikut:

a. Pilih dan klik menu Data-Validation, jendela data validation ditampilkan.

b. Data yang digunakan dalam penggunaan Nomor Anggota adalah kolom No pada sheet ANGGOTA, dalam kasus ini range telah diberi nama Kode. Selanjutnya pada tab Settings dalam Validation Criteria, pada:

- Field Allow, klik drop-down dan pilih List

- Field Source, tentukan sumber data, dalam kasus ini diisi dengan nama range (=Kode), karena telah diberi nama range - Kode, seperti Gambar 7. 


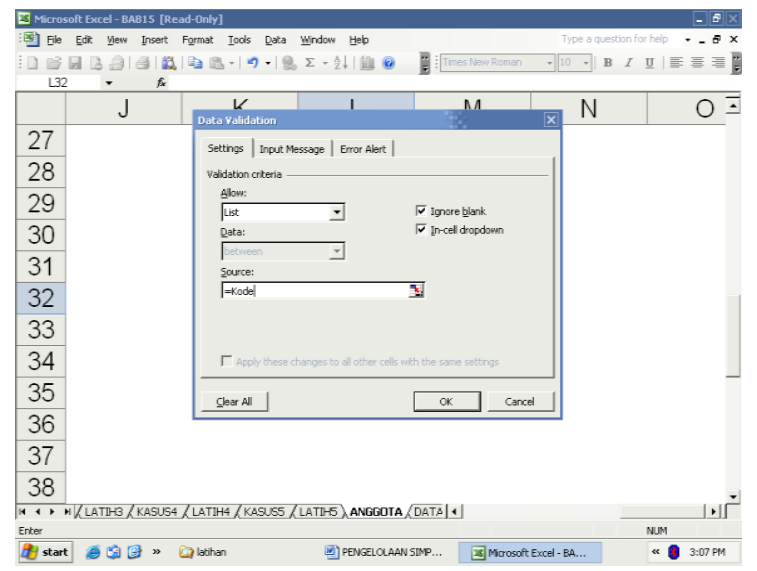

Gambar 7. Sumber Data

4. Pengisian data Nama menggunakan data pada sheet ANGGOTA menggunakan fungsi Index dengan kombinasi fungsi Match, sehingga pada sel D14 diisi dengan:

$=$ INDEX(Alamat;MATCH $(\$ D \$ 13 ;$ Kode;0);2).

Dengan mengaktifkan fungsi index, tampilan jendela fungsi tersebut untuk penyelesaian kasus dapat dilihat pada Gambar 8.

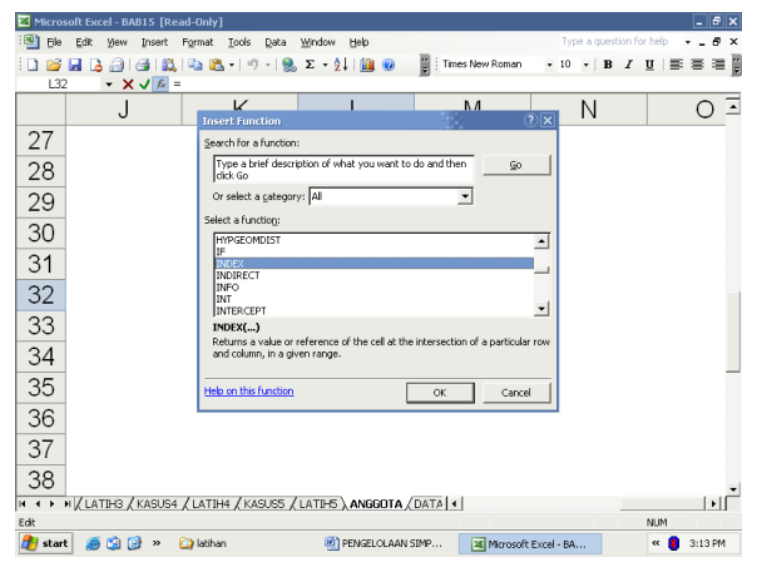

Gambar 8. Fungsi Index

5. Salin fungsi index pada sel D14 ke range D15:D18, selanjutnya edit nomor kolom (Column_num) dari 2 menjadi 3 (sel D15), nomor kolom 4 (sel D16), nomor kolom 5 (sel D17) dan nomor 6 (sel D18). Selengkapnya dapat dilihat pada range bersangkutan dalam buku kerja.

6. Pengisian field Data Peminjam, sebagian dilakukan secara manual, untuk pengisian jangka waktu pinjam dapat menggunakan fasilitas validasi data.

Asumsi yang digunakan untuk mengisi data Pokok Pinjaman, Provisi dan dana Risiko adalah berdasarkan keputusan rapat anggota tahunan (RAT). Contoh data tersimpan dalam sheet DATA1. Rumus untuk mengisi data pada sel H16 adalah $=\mathrm{H} \$ 15^{*}$ DATA!E6, selanjutnya salin rumus tersebut ke range H17:H18.

7. Fungsi yang digunakan dalam pengisian Tabel Angsuran adalah sebagai berikut:

a. Bulan ke - 1 (sel B26) diisi dengan fungsi $=\mathrm{IF}(\mathrm{H} 4=0$;"' 1 ), artinya pada sel B26 diisikan angka 1 jika pada sel H14 tidak berisi angka 0 (nol),

b. Bulan ke - 2 (sel B27) diisi dengan fungsi: 
$=\mathrm{IF}\left(\mathrm{B} 26="{ }^{\prime \prime}, ; " \prime \prime ; \mathrm{IF}(\mathrm{H} \$ 14 .=\mathrm{B} 26+1 ; \mathrm{B} 26+1 ; " \prime \prime)\right)$

c. Fungsi tersebut untuk membuat angka secara berurutan sampai dengan jangka waktu pinjam yang terdapat pada sel H14.

d. Bulan pembayaran angsuran mulai dari sel C22 diisi dengan asumsi pembayaran angsuran dilakukan satu bulan setelah pinjaman diterima, sehingga mulai dari sel tersebut diisi dengan fungsi:

$=\mathrm{IF}\left(\mathrm{B} 22="{ }^{\prime}, ; "\right.$ "EOMONTH(E\$15;B22)

e. Pokok pinjaman bulan ke - 1 (sel D26) diisi dengan fungsi:

$=\mathrm{IF}(\mathrm{B} 26="$ "';"'"; $\mathrm{H} 15)$

f. Pokok pinjaman bulan ke - 2 (sel D27) pada dasarnya merupakan Saldo Pokok Pinjaman dari bulan sebelumnya sehingga diisi dengan fungsi sebagai berikut:

$=\mathrm{IF}\left(\mathrm{B} 27="{ }^{\prime \prime}, ; " \prime \prime ; \mathrm{H} 26\right)$

g. Cicilan Pokok Pinjaman mulai dari sel E26 diisi dengan fungsi:

=IF(B26="'";"'”;IF(F\$5=3;PPMT(H\$13/12;B26;H \$14;-H\$15;1);H15/H\$14)

h. Bunga Pinjaman mulai dari sel F26 diisi dengan fungsi sebagai berikut: $=\mathrm{IF}\left(\mathrm{B} 26="{ }^{\prime \prime} ; " \prime \prime \prime\right) ; \mathrm{IF}\left(\mathrm{F} \$ 5=1 ;\left(\mathrm{D} 26^{*} \mathrm{H} \$ 13\right) / 12 ; \mathrm{IF}\left(\mathrm{F} \$ 5=2 ;\left(\mathrm{H} \$ 15^{*} \mathrm{H} \$ 13\right) / 12 ; \mathrm{IPMT}(\mathrm{H} \$ 1\right.\right.$ 3/12;B26; $\mathrm{H} \$ 14 ;-\mathrm{H} \$ 15 ; 1)))$ )

i. Angsuran per Bulan pada dasarnya merupakan Cicilan Pokok Pinjaman + Bunga, sehingga mulai sel G16 diisi dengan fungsi : +SUM(E26:F26)

j. Saldo Pokok Pinjaman pada dasarnya merupakan Pokok Pinjaman dikurangi dengan Cicilan Pokok Pinjaman, sehingga pada sel H26 diisi dengan fungsi sebagai berikut:

$=\mathrm{IF}\left(\mathrm{B} 26="{ }^{\prime \prime} ; "\right.$;"';H $\$ 15-\mathrm{SUM}(\mathrm{E} \$ 26: \mathrm{E} 26)$

k. Fungsi yang telah disebutkan di atas disalin sampai dengan jumlah baris batas maksimal jangka waktu pinjam.

\section{Kartu Angsuran Pinjaman}

Berdasarkan data pada sheet kasus 6, dapat dibuat kartu angsuran pinjaman yang untuk pencatatan transaksi pembayaran yang dilakukan oleh anggota. Salah satu contoh bentuk kartu tersebut dapat dilihat pada sheet TABEL seperti diperlihatkan pada Gambar 9 berikut:

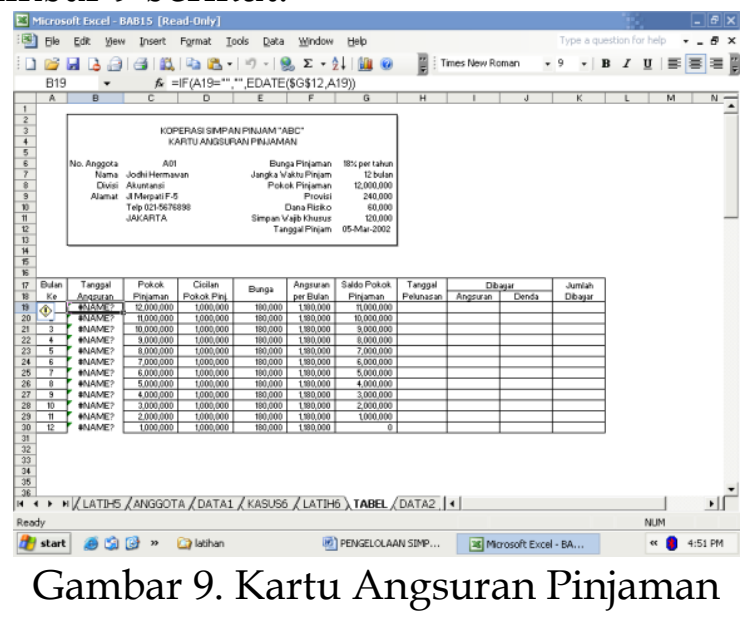


Bentuk atauformat tabel angsuran pinjaman yang telah dibahas, dapat dimodifikasi sesuai dengan ketentuan yang berlaku pada koperasi yang dijalankan.

\section{Bunga Simpanan}

Salah satu aktivitas koperasi simpan pinjam atau unit simpan pinjam adalah menghimpun dana dari anggota koperasi. Untuk itu diperlukan cara menghitung bunga simpanan anggota koperasi, khususnya untuk koperasi yang belum memiliki program berbasis komputer. Program tersebut dapat dioptimalkan untuk perhitungan bunga simpanan anggota dengan bunga harian maupun kelipatan angka tertentu.

\section{Materi Studi Kasus 1}

Sebuah koperasi simpan pinjam mempunyai data seperti ditunjukkan pada tabel 3.

Tabel 3. Data Koperasi Simpan Pinjam

\begin{tabular}{llll}
\hline Sumber Dana & Jumlah (Rp) & Biaya Dana & Cadangan Wajib \\
\hline Simpanan Pokok & 60.000 .000 & $10 \%$ & $15 \%$ \\
\hline Simpanan Wajib & 60.000 .000 & $12 \%$ & $10 \%$ \\
\hline Simpanan Sukarela & 80.000 .000 & $16 \%$ & $10 \%$ \\
\hline Pinjaman & 200.000 .000 & $18 \%$ & $10 \%$ \\
\hline Total & 400.000 .000 & &
\end{tabular}

Berdasarkan data tersebut dapat dihitung kontribusi masing-masing biaya dana dengan alat bantu Excel, sehingga didapatkan total biaya dana. Prosedur penyelesaian kasus tersebut adalah:

1. Susunlah data ke dalam buku kerja, seperti diperlihatkan pada sheet berikut:

Data : sumber dana, jumlah, biaya dana dan cadangan wajib diisi manual. Jumlahkan data pada baris. Totalkan dengan menggunakan fungsi SUM

2. Format data mlalui menu Format-Cells tab Number dan pilih Percentage untuk engisian data kolom PDT, BD, CAD, BDE dan KMDB sehingga hasilnya berupa agka dalam format persen.

Persentase dari Total (PDT dihitung dari masing-masing sumber dana dibagi dengan total sumber dana sehingga rumus pada sel D7 adalah $=\mathbf{C 7 / C} \mathbf{\$ 1 1}$ Hasinya terlihat pada Gambar 10.

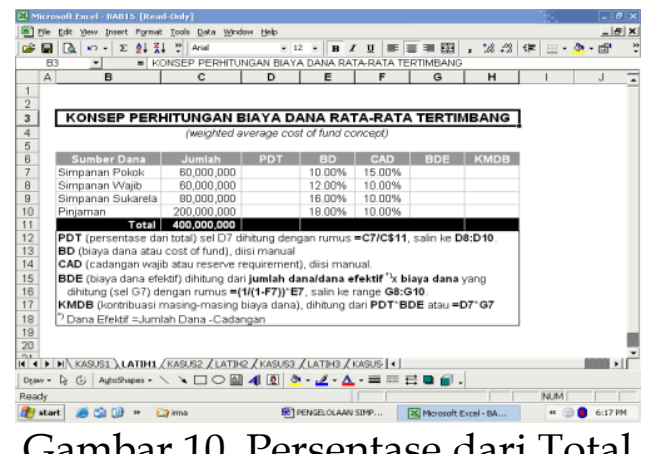

3. Biaya Dana Efektif (BDE) dihitung berdasarkan data biaya dana/dana efektif dan hasilnya dikalikan dengan biaya dana. Dana efektif adalah jumlah dana dikurangi dengan cadangan wajib, sehingga rumus pada sel G7 adalah $=(\mathbf{1} /(\mathbf{1}$ F7))*E7 
4. Kontribusi Masing-Masing Biaya Dana (KMDB) dihitung dari PDT $x$ BDE, sehingga rumus pada sel $\mathbf{H} 7$ adalah $=\mathrm{D} 7 * \mathrm{G} 7$

Hasilnya terlihat pada Gambar 11.

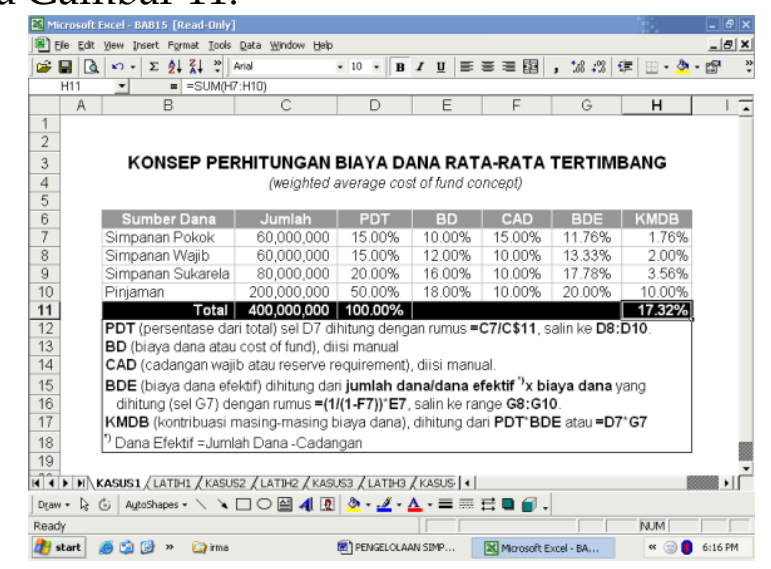

Gambar 11. Biaya Dana Efektif

Berdasarkan perhitungan tersebut, diperoeh angka otal Biaya Dana sebesar 17,32\%. Untuk menentukan besarnya base lending rate BLR) - dasar pokok penjualan bunga pinjaman kepada naggota, calon anggota, maka pihak koperasi memperhitungkan komponen antara lain keuntungan yang diharapkan (spread), cadangan risiko (risk allowance), overhead pencadangan dan pajak (tax).

\section{Materi Studi Kasus 2}

Sebuah koperasi simpan pinjam mempunyai data biaya dana seperti perhitungan sebelumnya dan data lain sebagai berikut:

1. Keuntungan yang diharapkan (spread) sebesar $1,5 \%$

2. Cadangan risiko (risk allowance) sebesar $0,5 \%$

3. Overhead pencadangan sebesar $1 \%$

4. Pajak (tax) sebesar $10 \%$

Prosedur untunk menghitung besarnya bunga pinjaman yang diberikan oleh koperasi kepada anggota adalah:

1. Aktifkan untuk kasus 2

2. Masukkan rumus dan fungsi seperti berikut:
a. Sel E3 = KASUS 1!H11
b. Sel E7 = SUM(E3:E6)
c. Sel E8 = C8*E4
d. Sel E9 = SUM(E7:E8)

Hasilnya terlihat pada Gambar 12. Berdasarkan data tersebut, maka bunga pinjaman untuk anggota koperasi sebesar $20,47 \%$. 


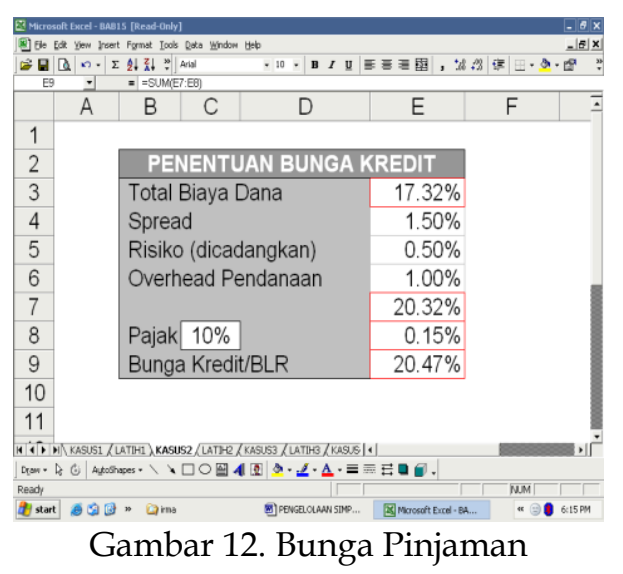

\section{Materi Studi Kasus 3}

Sebuah koperasi menghendaki sebuah tabel untuk menghitung angsuran yang harus dibayar oleh peminjam dengan sistem sliding. Tabel tersebut harus memuat informasi bulan pembayaran (pembayaran pertama dimulai sebulan setelah meminjam), pokok pinjaman, cicilan pokok pinjaman, bunga, angsuran per bulan dan saldo pokok pinjaman. Data pinjaman adalah sebagai berikut:

a. Bunga pinjaman per tahun $20 \%$

b. Jangka waktu pinjaman 12 bulan

c. Pokok pinjaman Rp 5.000.000,00

Prosedur penyelesaian kasus adalah sebagai berikut:

1. Aktifkan sheet seperti ditunjukkan melalui Gambar 13 berikut:

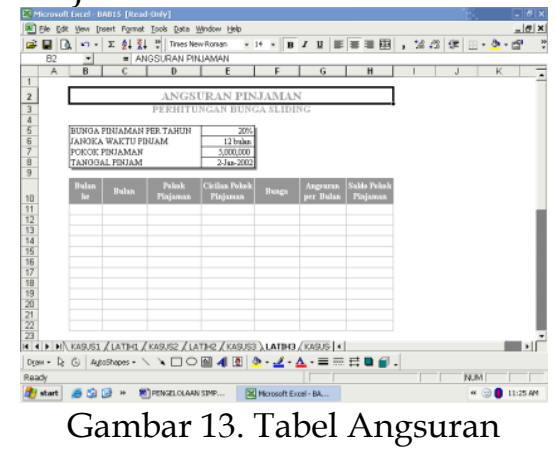

2. Fungsi yang dihasilkan untuk menyelesaikan kasus adalah sebagai berikut:

- Sel B11=IF(E6=0;" ";1)

- Sel B12 =IF(B11=""',"'; $\mathrm{IF}(\mathrm{E} \$ 6>=\mathrm{B} 11+1 ; " \prime))$

- Sel C11 =IF(B11="'","';EMONTH(E\$8;B11)

- Sel D11 =IF(B11 $="$ "';E7)

- Sel E11 =IF(B11="',;"';E\$7E\$6)

- Sel F11 =IF(B11="',;"';(D11*E\$5)/12

- Sel G11 =IF(B11="";",";E11+F11)

- Sel H11 =IF(B11=""';"'";E\$7-SUM(eS11:E11)

- Salin fungsi yang terdapat pada sel B12 ke range B13:B22

- Salin fungsi yang terdapat pada range C11:H!! ke range C12:H22, seperti ditunjukkan dalam Gambar 14. 


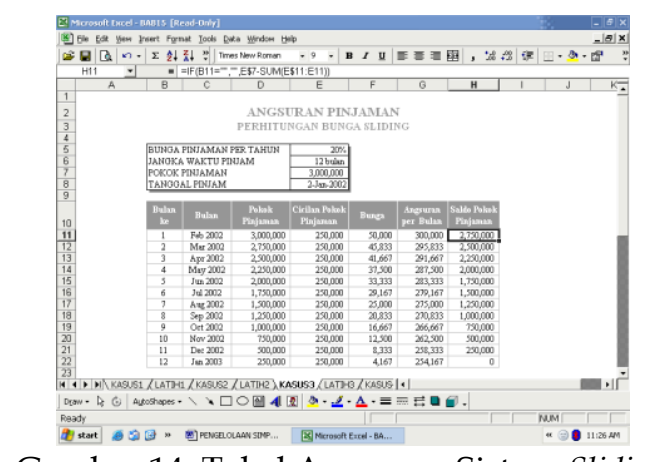

Gambar 14. Tabel Angsuran Sistem Sliding

3. Agar tabel tampil secara otomatis sesuai dengan jumlah bulan pinjaman, lakukan hal sebagai berikut:

- Sorot range B11:H22

- Pilih dan klik menu Format - Conditional Formatting, jendela Conditional Formatting. Lakukan format kondisional sehingga tampilan jendela tersebut terlihat seperti Gambar 15 berikut:

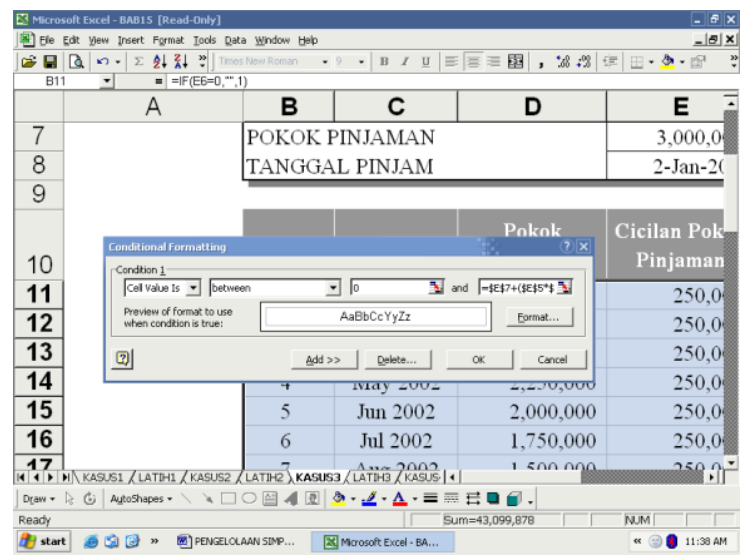

Gambar 15. Format Tabel Angsuran Sistem Sliding

Format konsional dapat dilihat secara rinci denganmenempatkan petunjuk sel pada range B11:H22 dan klik menu Format - Conditional Formatting.

Jika ingin menambah periode waktu pinjam dan jumlah baris pada tabel secara otomatis (pada contoh kasus selama 2 tahun), sorot baris terakhir dari tabel selanjutnya salin sesuai dengan kebutuhan.

Masalah yang mungkin terjadi pada program aplikasi Excel pada komputer adalah belum terinstal fungsi EOMONTH. Jika hal ini terjadi, pada kolom Bulan akan terisi \#NAME?, berarti Anda harus menginstal fungsi tersebut dengan prosedur berikut:

1. Pilih dan klik menu Tools - Add-Ins, jendela Add-Ins ditampilkan

2. Tandai kotak periksa fiels Analysisi ToolPak dan Analysis ToolPak-VBA, lihat Gambar 16. 


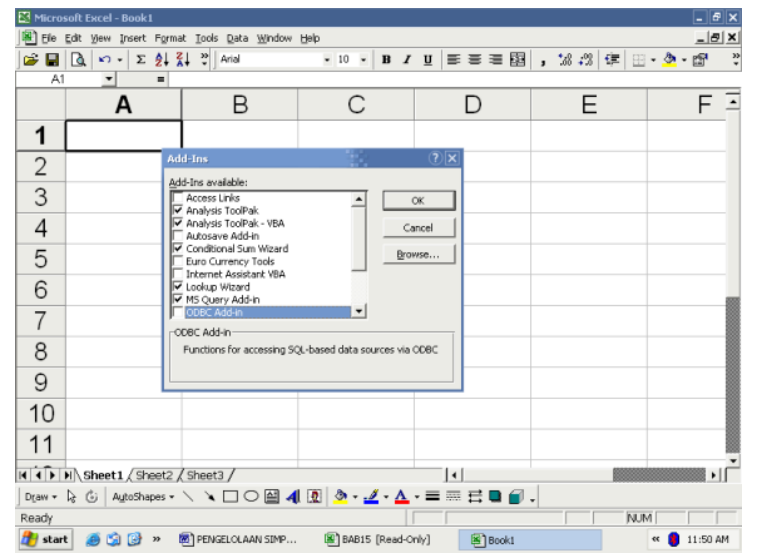

Gambar 16. Fungsi EOMONTH

3. Klik tombol OK, tunggu sejenak proses instalasi akan dilakukan. Jika komputer Anda meminta Anda memasukkan program Microsoft Office, masukkan program tersebut pada drive CD ROM. Langkah selanjutnya ikuti perintah yang terdapat pada monitor.

\section{Materi Studi Kasus 4}

Sama dengan studi kasus 3, hanya terdapat perubahan pada sistem bunga dari sliding ke sistem bunga flat.

Prosedur penyelesaian kasus adalah sebagai berikut:

1. Aktifkan sheet

2. Fungsi penyelesaian kasus pada prinsipnya sama dengan studi kasus 3. Perbedaan terdapat pada perhitungan bunga pinjama pada sel F11, yaitu $=\mathrm{IF}(\mathrm{B} 11=" \prime \prime \prime \prime \prime) ;\left(\mathrm{E} \% 7^{*} \mathrm{E} \$ 5\right) / 12$, selanjutnya salain ke range $\mathrm{F} 12: F 22$, sebagamana terdapat pada Gambar 17.

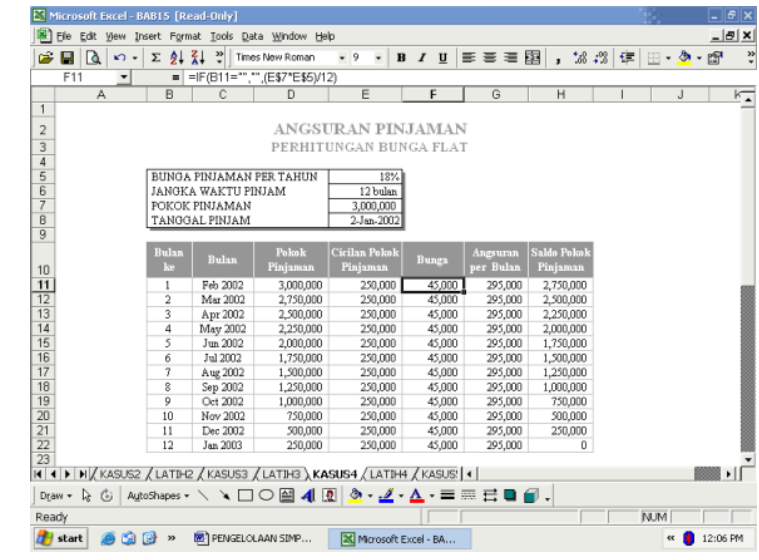

Gambar 17. Sistem Flat 


\section{Materi Studi Kasus 5}

Sama dengan studi kasus 3 maupun 4 dengan perbedaan sistem yang dipakai, yaitu sistem efektif.

Prosedur penyelesaian kasus adalah sebagai berikut:

1. Aktifkan sheet.

2. Fungsi untuk menyelesaikan kasus sebagian sama dengannpenyelesian kasus 3 dan 4. Perbedaan terletak pada fungsi untuk mencari Cicilan Pokok Pinjaman, Bunga Pinjaman dan Angsuran per Bulan seperti dijelaskan berikut:

- Sel E11 =IF(B11 ="";"'",PPMT(E\$5/12;B11;E\$6;-E47;1))

- Sel F11 =IPMT(E\$5/12;B11;E\$6;-E47;1)

- Sel G11 =PMT(E\$5/12;E\$6;-E\$7)

Angsuran pinjaman pada dasarnya merupakan jumlah yang dibayar oleh naabah atau anggota koperasi atas bunga pinjaman dan cicilan pokok yang besarnya tergantung jumlah pinjaman dan cara perhitungan yang dipakai.

Hasilnya dapat dilihat melalui Gambar 18 berikut:

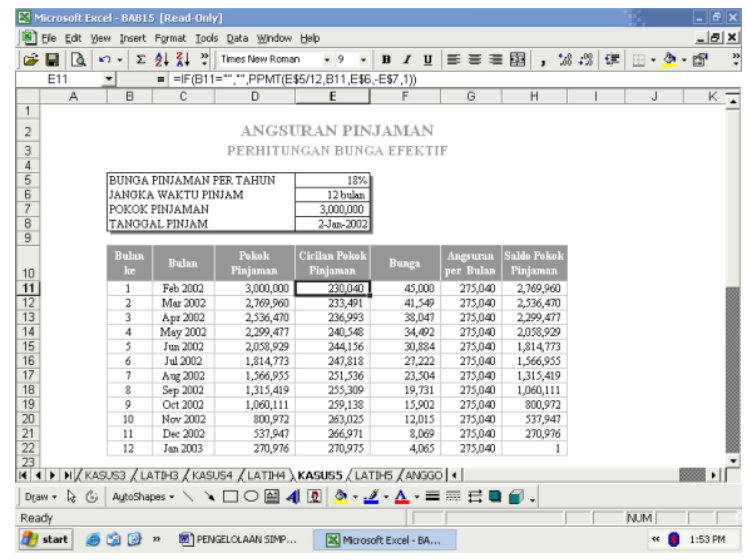

Gambar 18. Sistem Efektif

\section{Materi Studi Kasus 6}

Studi kasus ini akan mengetengahkan bagaimana membuat sebuah tabel angsuran pinjaman berdasarkan data tingkat suku bunga, pokok pinjaman dan jangka waktu pinjam menggunakan beberapa sistem yang dapat dipilih.

Pada gambar tersebut, untuk memilih antara Bunga Pinjaman (1) dilakukan dengan klik tanda panah ke atas atau ke bawah, Data Peminjam (2) dilakukan dengan mengklik drop-down field Nomor Anggota dan Data Pinjaman (3) sebagian diisi secara manual. Contoh penerapan dapat dilihat melalui Gambar 19 berikut: 


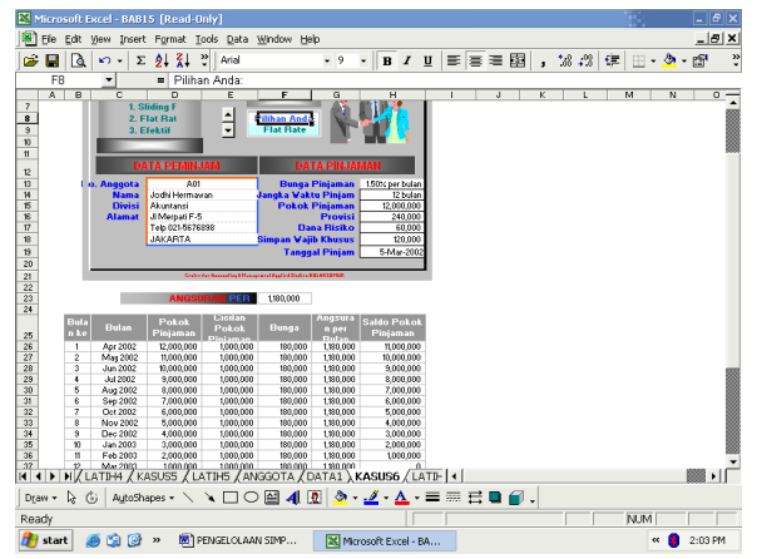

Gambar 19. Data Pinjaman Lengkap

\section{Materi Studi kasus 7}

Pengurus koperasi menginginkan suatu tabel untuk menghitung bunga simpanan berdasarkan hari dana tersebut tersimpan di koperasi. Data yang tercantum dalam tabel adalah tingkat bunga simpanan, pajak atas bunga, administrasi. Kolom transaksi diperlukan untuk mencatat transaksi penerimaan maupun penarikan dana, selanjutnya dibuat tabel perhitungan bunga. Contoh tabel untuk menghitung simpanan dengan bunga harian dapat dilihat melalui Gambar 20 berikut:

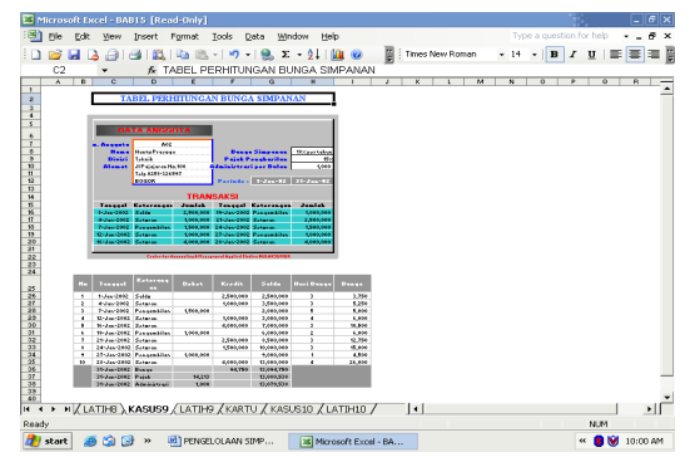

Gambar 20. Perhitungan Simpanan dengan Bunga Harian

Prosedur pembuatan tabel tersebut pada prinsipnya tidak jauh berbeda dengan materi yang telah dibahas sebelumnya. Penggunaan rumus, fungsi dan vasilitas lain dapat dilihat pada sheet yang bersangkutan.

Prosedur penggunaan data dalam sheet Kasus 7 adalah sebagai berikut:

1. Klik tanda panah ke bawah (drop-down) yang terdapat pada sel D7 untuk menampilkan data penyimpan atau anggota koperasi.

2. Isi data bunga simpanan, tarif pajak dan biaya administrasi range H8:H10.

3. Tentukan periode perhitungan bunga simpanan pada range G12:G13.

4. Isi data transaksi yang terdapat pada range C16:H20.

5. Hasil perhitungan bunga, pajak, biaya administrasi dan saldo akhir periode secara otomatis akan ditampilkan dalam kasus ini pada range D36:G38.

Misalkan periode perhitungan bunga simpanan mulai dari tanggal 1 Januari 2002 sampai dengan 31 Janusri 2002. Jika dimasukkan tanggal transaksi pada range C16:C20 atau F16:F20 di luar tanggal tersebut secara otomatis komputer akan 
memberikan peringatan bahwa tanggal tidak sesuai dengan periode yang ditetapkan. Proses pembatasan input data tanggal transaksi tersebut dilakukan dengan prosedur sebagai berikut:

1. Pilih atau sorot range C16:C20 dan F16:F20

2. Pilih dan klik menu Data - Validation, jendela Data Validation ditampilkan

a. Tab Settings dan isi data seperti tampilan pada Gambar 21 berikut:

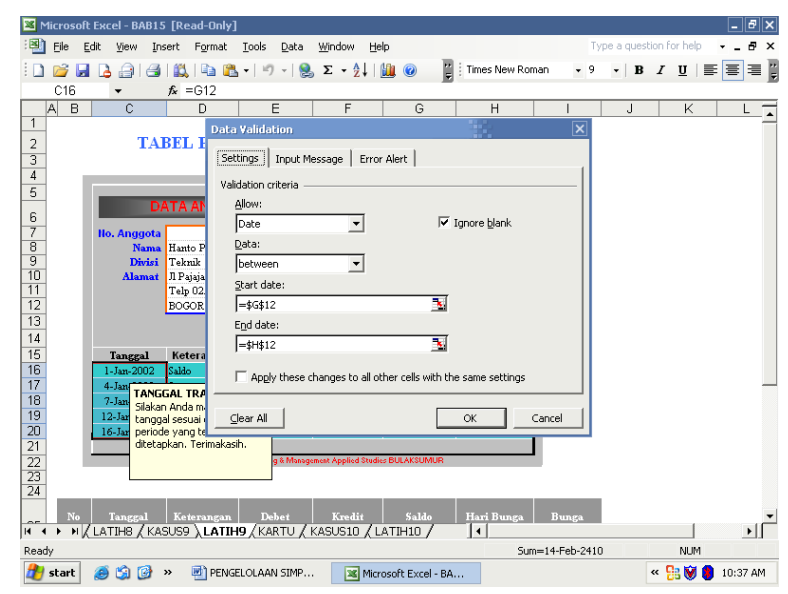

Gambar 21. Proses Pembatasan Input

b. Tab Input Message, isi pesan atau penjelasan untuk user pada saat mengisi tanggal transaksi, salah satu contoh dapat dilihat melalui Gambar 22 berikut.

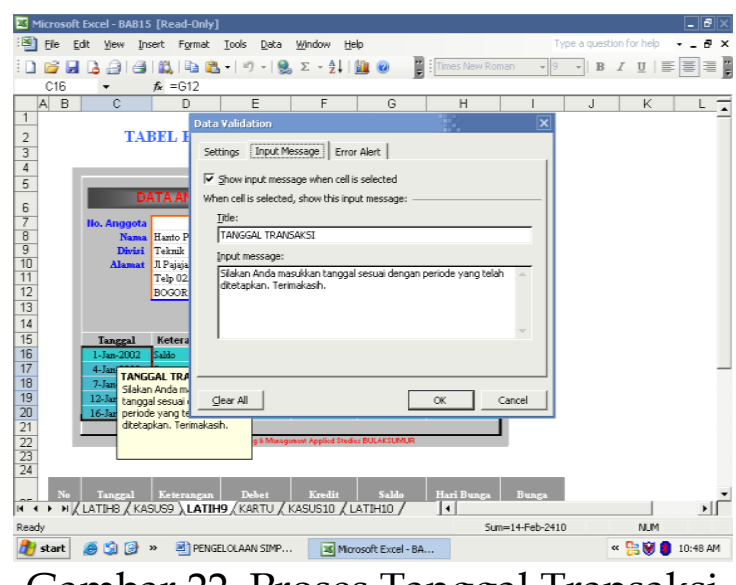

Gambar 22. Proses Tanggal Transaksi

c. Tab Error Alert, diisi komentar jika data masukan salah, contoh dapat dilihat pada gambar berikut:

3. Klik tombol perintah OK.

Jika dibutuhkan kartu simpanan untuk transaksi manual, telah disediakan tabel pada sheet KARTU. Data pada sheet tersebut dilengkapi dengan fungsi untuk menghitung saldo yang dapat mulai dari alamat sel H10, seperti Gambar 23. 


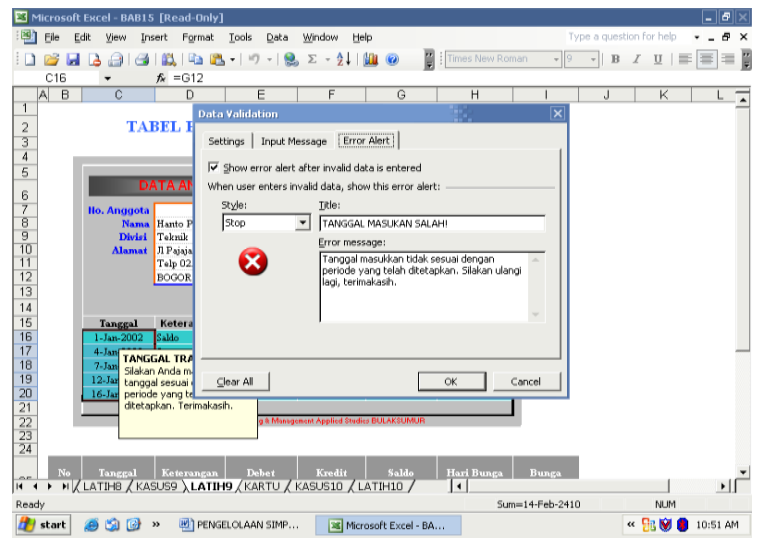

Gambar 23. Kartu Simpanan

\section{Materi Studi kasus 8}

Sebuah koperasi memutuskan untuk menghitung bunga simpanan anggota berdasarkan kelipatan Rp50.000,00 dengan tingkat bunga per bulan sebesar $1 \%$. Berdasarkan ketetapan tersebut susun tabel untuk perhitungan bunga simpanan.

Prosedur untuk membuat tabel simpanan anggota adalah sebagai berikut:

1. Aktifkan sheet.

2. Isi data bunga simpanan per bulan dan kelipatan perhitungan bunga pada range E6:E7. Selain data tersebut, dapat dimasukkan nomor anggota dan jumlah simpanan.

3. Dana simpanan anggota yang dikenai bunga meulai dari alamat sel E11 diisi fungsi $=$ ROUNDDOWN $\left.(\mathrm{E} 10 / \$ \mathrm{E} \$ 7 ; 0)^{*} \mathrm{E} 7\right)$

4. Bunga simpanan anggota mulai dari alamat sel E12 dihitung dengan rumus berikut $=\$ E \$ 6 *$ E11

5. Salin fungsi dan rumus dari range E11:E12 ke seluruh range data anggota, dalam kasus ini ke range F11:I12.

Hasilnya dapat dilihat melalui Gambar 24 berikut:

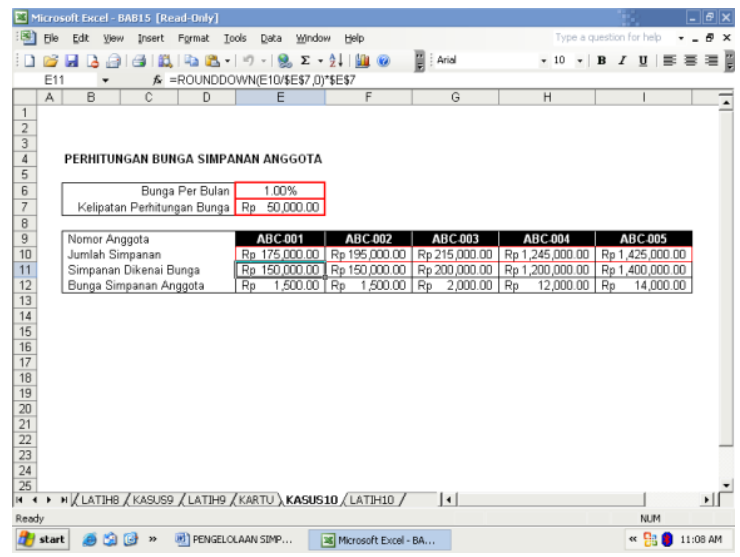

Gambar 24. Perhitungan Bunga Simpanan Anggota 
Selain pembuatan tabel bunga simpanan anggota dengan berdasarkan kelipatan tertentu, dapat dikembangkan berdasarkan saldo rata-rata atau berdasarkan data simpanan pada sampai dengan tanggal tertentu.

\section{Simpulan Dan Rekomendasi}

Karakter profesionalitas perlu dibentuk sejak dini. Hal ini menuntut keterlibatan setiap pihak baik di rumah, sekolah maupun peran serta berbagai pihak antara lain pemerintah dan lingkungan.

Konsep kekeluargaan yng dibentuk guru dengan mendirikn koperasi,dpat meningkatkan kesejahteraan guru dan pemberdayaan bentuk usaha yang merupakan soko guru ekonomi Indonesia, bila dilakukan dengan tertib dan profesional.

Adapun saran yang direkomendasikan adalah perlunya berbagai pelatihan pengembangan sumber daya manusia termasuk bagaimana menyusun menggunakan seperangkat alat yang mempunyai teknologi untuk memudahkan pekerjaan guru yang diberi tugas mengurus koperasi, sehingga pekerjaan utamanya sebagai guru tidak terbengkalai. Tahap ini adalah awal untuk menstimulus pelatihan-pelatihan sejenis. Selajutnya perlu kerjasama dan linkage program antara sekolah, perguruan tinggi dan praktisi pendidikan dalam pelatihan sejenis perlu dilakukan untuk semakin memperbaiki mutu dan muatan kperasi. Pelatihan sejenis perlu dilakukan lebih kontinyu dan terstruktur.

\section{Daftar Pustaka}

Muljono, D. (2012). Buku pintar Strategi bisnis koperasi simpan pinjam.

Aini, A., \& Setiawan, A. H. (2006). Analisis Faktor-Faktor Yang Mempengaruhi Paritisipasi Anggota Koperasi Serba Usaha (KSU) Unit Usaha Simpan Pinjam (USP) Karyawan Pemerintah Daerah Kota Semarang. Jurnal Dinamika Pembangunan, 3(2), 184-195.

Ayuk, N. M. T., \& Utama, I. M. S. (2011). Pinjaman Dan Jumlah Modal Kerja Terhadap Sisa Hasil Mempengaruhi Sisa Hasil Usaha KUD Turen ". Diperoleh Nilai koefisien determinasi sebesar. E-Journal Universitas Udayana, 629-646.

Cahyani, M. T. (2015). Pengaruh Jumlah Anggota Terhadap Perolehan Sebagai Variabel Intervening Pada Koperasi Simpan Pinjam Wisuda Guna Raharja Denpasar Tahun 2012-2014. Jurusan Pendidikan Ekonomi (JJPE), 5(1), 1-10.

Kantor Kepresidenan Republik Indonesia. (2012). Undang-Undang No. 17 Tahun 2012 tentang Perkoperasian.

Saraswati, L., \& Yadnyana, I. K. (2014). Pengaruh Struktur Pengendalian Intern Terhadap Kelancaran Pengembalian Kredit Pada Koperasi Simpan Pinjam Di Kota Denpasar. Jurnal Akuntansi Universitas Udayana, 7(1), 122-134. 


\section{JURNAL ABDIMAS UBJ}

Setiawan, A. B. (2002). Recharging Metode Pembelajaran Kewirausahaan Berbasis Multimedia. 